\title{
Achieving employee support during the COVID-19 pandemic - the role of relational and informational crisis communication in Austrian organizations
}

Employee support during the COVID-19 pandemic

\author{
Sabine Einwiller, Christopher Ruppel and Julia Stranzl \\ Department of Communication, Faculty of Social Sciences, University of Vienna, \\ Vienna, Austria
}

\begin{abstract}
Purpose - Based on social exchange theory, the study examines the influence of informational and relational internal communication on cognitive and affective responses and job engagement during organizational crises caused by the COVID-19 pandemic.

Design/methodology/approach - Data were collected by means of an online survey among people working in organizations with a minimum of 10 employees $(N=1,033)$ and analyzed using structural equation modeling.

Findings - Results show that informational and relational communication as organizational resources have a significant but distinct influence on how employees support their employer during the crisis. While informational communication influences employees' acceptance of managerial decisions, relational communication exerts most influence on affective commitment, which is the strongest driver of job engagement.
\end{abstract}

Research limitations/implications - The cross-sectional design, specific crisis situation and geographic location are limitations of the study.

Practical implications - Delivering relevant information to employees quickly and reliably is important. Yet, relationship-oriented communication that demonstrates appreciation and allows for participation has even stronger effects on job engagement, which is essential to mastering challenges arising from a crisis.

Social implications - During the COVID-19 pandemic, organizations demanded much from their employees. In exchange, organizations should provide the resources information, status and love (Foa and Foa, 1980) by means of internal crisis communication.

Originality/value - The study demonstrates the role of different types of internal communication during organizational crises used to convey organizational resources, and it highlights the mediating role of acceptance and commitment to enhance employees' engagement at work.

Keywords Internal communication, Employee engagement, Crisis communication, Corporate communication Paper type Research paper

\section{Introduction}

Set off by the novel coronavirus, which spread rapidly from China all over the world, a crisis of extraordinary proportions broke out in Europe in February/March 2020, causing shutdowns in

(C) Sabine Einwiller, Christopher Ruppel and Julia Stranzl. Published by Emerald Publishing Limited. This article is published under the Creative Commons Attribution (CC BY 4.0) licence. Anyone may reproduce, distribute, translate and create derivative works of this article (for both commercial and noncommercial purposes), subject to full attribution to the original publication and authors. The full terms of this licence may be seen at http://creativecommons.org/licences/by/4.0/legalcode.

The research was funded by the University of Vienna (grant to the first author).

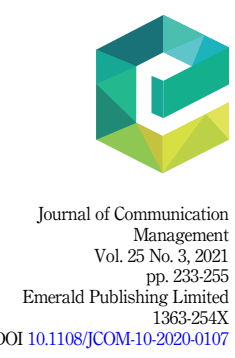

Received 1 October 2020

Revised 4 February 2021 9 April 2021

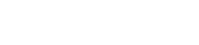


$\mathrm{JCOM}$ 25,3

most countries, including Austria. Due to the strict measures ordered by the Austrian government to contain the COVID-19 pandemic, many organizations faced severe operational disruptions due to this health emergency, often with serious economic consequences. As a result, many organizations experienced an organizational crisis, which is "an unpredictable event that threatens important expectancies of stakeholders related to health, safety, environmental, and economic issues, and can seriously impact an organization's performance and generate negative outcomes" (Coombs, 2015, p. 3). Depending on the industry sector, some organizations had to close completely or operate at a reduced capacity, while others worked even harder to maintain public support for healthcare and everyday goods. The effects of the crisis were serious for many employees and ranged from changed working conditions in their home office, strict health regulations at the workplace, to salary-cuts due to short-time work and job loss (Czypionka et al., 2020).

Changed working conditions and high personal and job-related uncertainty have been shown to put job engagement on trial (Asfaw and Chang, 2019). Yet, during the COVID-19 pandemic, organizations desperately needed their employees' continued job engagement (Mani and Mishra, 2020) in order to maintain their ability to communicate, collaborate and function properly and to mitigate negative economic consequences (Heide and Simonsson, 2019). Because organizations' top management had to act and make critical decisions quickly, especially during the early stages of the pandemic, they also depended on their workforce's acceptance and realization of their decisions, as employees are usually the ones who have to actively solve the situation (Heide and Simonsson, 2020).

This shows that organizations' management asked much from their workforce during the COVID-19 pandemic, which affected not only people's work but also their private lives. As argued in social exchange theory, relationships are based on reciprocity (Blau, 1964; Cropanzano and Mitchell, 2005). Thus, to receive expansive cognitive, emotional and physical support from employees during the pandemic, organizations' management needed to also provide support to their employees. Aside from economic compensations, Blau (1964) emphasizes the role of cognitive as well as emotional resources, which are particularly important in a crisis context.

According to Heide and Simonsson $(2019,2020)$, the initial focus of internal crisis communication is the provision of instructional information through all available channels, closely followed by providing platforms for discussion. In addition to these informational resources, it is important that organizations provide emotional resources for their personnel. This can be done by listening and responding to employees' concerns and needs during the difficult situation (Mazzei and Ravazzani, 2015) and by acknowledging and thanking them for their hardship and efforts (Dirani et al., 2020). Both informational and emotional resources, yet of different kinds, can be provided by means of internal crisis communication. While the former relies on an informational communication strategy, the latter requires a relationship-oriented communication strategy including participatory and appreciative forms of communication. Extant research confirms the impact of different internal communication strategies on employees' job engagement during stable economic times (e.g. Jiang and Shen, 2020; Jiang and Men, 2017; Men and Stacks, 2014) that yield positive organizational outcomes (Biswas and Bhatnagar, 2013; Kang and Sung, 2017; Saks, 2006; Shen and Jiang, 2019; Yin, 2018). Hence, the question guiding this research is as follows:

$R Q 1$. How does internal crisis communication of informational and relational types during organizational crises caused by the COVID-19 pandemic help foster favorable cognitive and affective responses as well as job engagement in employees? 
The present study strengthens our understanding of the role of internal crisis communication during a global pandemic that caused crisis situations in many organizations, focusing on communicative interaction among managers and employees during the crisis, but not before and after (Johansen et al., 2012). Based on social exchange theory (Blau, 1964; Cropanzano and Mitchell, 2005), the study sheds light on the effects of informational and relational resources provided by the organization through communication on employees' cognitive and affective responses and, consequently, on their job engagement. By differentiating various resources fostering social exchange between an organization and its employees during a crisis, this research contributes to theory building in internal crisis communication. It furthermore generates managerial knowledge regarding ways to foster job engagement in employees and possibly prevent undesirable states such as disengagement.

In the following, we first outline the social exchange theory as a theoretical foundation before elaborating on the role of informational and relational crisis communication in fostering cognitive and affective responses in employees and, consequently, job engagement. The hypotheses derived from the literature were tested by means of survey research among people employed in organizations located in Austria during the first shutdown phase of the COVID-19 pandemic. The presentation of results is followed by discussion, implications and limitations.

\section{Literature review}

Social exchange theory in the working context during a crisis

Social exchange theory is an influential conceptual paradigm that regards social life as including a series of sequential transactions between two or more parties whereby resources are exchanged through a process of reciprocity (Cropanzano et al., 2017). In the organizational context, social exchange theory describes how the deployment of organizational resources results in employees' reciprocation in terms of pro-social attitudes and behavior (Blau, 1964). These interdependent transactions, where "something has to be given and something returned" (p. 876), can foster and stabilize high-quality relationships (Cropanzano and Mitchell, 2005), which is particularly crucial during a crisis when organizations and employees depend on one another even more than in normal times. To engender reciprocal support in employees, organizations need to provide resources in turn.

Foa and Foa (1980) identified six categories of social resources that systematically interact and can be transacted in an interpersonal situation: money, goods, services, information, status and love. Information, status and love are typically symbolic and mediated through verbal or paralinguistic behaviors. According to Blau (1964), organizations can provide these to their personnel in exchange for their supportive emotions, cognitions and behavior. While economic resources that include money, goods and services are certainly important in a working context, the resources relevant in a social exchange are predominantly socialemotional. This is even more so in times of scarce economic resources (Foa and Foa, 1980), as was the case in many organizations in Austria during the COVID-19 pandemic, when about every fourth employee had to accept salary cuts due to short-time work (Hager, 2020).

As information, status and love can be transmitted and expressed verbally, internal communication between an organization and its employees is a key mechanism with which to foster reciprocal social exchange. The need for these resources is reflected in a survey among US employees conducted during the COVID-19 pandemic. Here, Orangefiery (2020) found that employees demanded more information about what the organization knows and does not know about the situation and about how employees can deal with their stress and anxiety, as well as stronger acknowledgement of their difficult situation and hardships. Thus, aside from providing helpful and instructive information, which is relevant during the acute phase of a crisis (Heide and Simonsson, 2019), employees want to receive emotional resources that help

\section{Employee support during the COVID-19 pandemic}

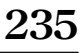


$\mathrm{JCOM}$ 25,3

them to better deal with the situation and that also help to foster the employee-organization relationship. Accordingly, we differentiate between informational and relational internal crisis communication to provide the social resources which can help foster employee support during a crisis.

One important way in which employees repay their organization is through their level of engagement (Saks, 2006). "Bringing oneself more fully into one's work roles and devoting greater amounts of cognitive, emotional, and physical resources is a very profound way for individuals to respond to an organization's actions" (Saks, 2006, p. 603). An engaged workforce is highly relevant to the achievement of organizational goals, the future direction of an organization (Men and Bowen, 2017), as well as organizational success and competitiveness (Saks and Gruman, 2014). However, when an organization fails to provide adequate resources, employees are more likely to withdraw and disengage themselves from their roles and to cognitively, physically and emotionally reduce their normal work roles (Kahn, 1990; Wollard, 2011). Another way in which an organization's resources can be reciprocated by employees is through showing commitment (Cropanzano and Mitchell, 2005). Rhoades et al. (2001) demonstrated that the emotional component of commitment - affective commitment (Allen and Meyer, 1990) - in particular is reciprocated by employees in return for their organization's support. Affective commitment can then lead to a wide range of outcomes, including engagement, as committed employees demonstrate more energy to help their organization succeed (Markos and Sridevi, 2010). During the COVID-19 pandemic, organizations were under pressure to make decisions quickly, of which several were unfavorable for employees, such as reduced salaries (Absolventa, 2020), strict hygiene rules and installing an office space at home. To maintain the ability to function properly during the crisis, organizations needed their workforce's acceptance and realization of their decisions. Thus, in this critical situation, acceptance of managerial decisions was an important resource which organizations needed from their employees in return for their organizational support.

In sum, social exchange theory helps to model the reciprocal exchange between an organization and its employees during organizational crisis situations like those elicited by the COVID-19 pandemic. The amount of supportive resources that an individual employee is willing to reciprocate to his or her employer is contingent on the resources received from the work organization, which comprise informational and relational forms of internal communication. In turn, to maintain the ability to communicate, collaborate and function properly (Heide and Simonsson, 2019), the resources organizations need from their workforce include cognitive acceptance of managerial decisions and emotional support as expressed in affective commitment. We assume that these cognitive and emotional resources consequently engender employees' willingness to bring themselves fully into their work roles, i.e. job engagement (Saks, 2006), as a key resource that helps organizations mitigate negative economic consequences.

\section{Internal crisis communication as an organizational resource}

Communication during a crisis is an important means of conveying symbolic social resources that engender employee support. If communication is deficient during a crisis so that employees do not receive important information or feel excluded or forgotten, their desire to contribute to management of the crisis can be severely compromised (Frandsen and Johansen, 2011). As argued above, the three social resources - information, status and lovewere particularly relevant during the COVID-19 pandemic. According to Foa and Foa (1980), "information includes advice, opinions, instruction, or enlightenment, but excludes those behaviors which could be classed as love or status" (p. 79). Love as a resource is an expression of affectionate regard, warmth or comfort, while status refers to an expression of evaluative judgment conveying regard or esteem. 
The communication of each of these three resources has distinct functions because they pursue different goals. By conveying information, organizations primarily aim at creating understanding in their workforce (Heide and Simonsson, 2020; Rawlins, 2009). Such informational crisis communication is meant to generate acceptance of management's decisions, which is an important resource, especially during a crisis. Providing status by conveying regard or esteem and expressing love or appreciation aim at strengthening the emotional bond or affective commitment between an organization and its employees, which as well is an important resource for the organization. As commitment is a core element of relationships (Bruning and Ledingham, 1999; Huang, 2001), we speak of relational crisis communication in this regard.

Informational crisis communication and its effects. Informational crisis communication is the means by which to provide the resource, information. In an acute crisis, providing instructional information is considered particularly important (Heide and Simonsson, 2019, 2020). Instructional guidance to maintain workplace safety during the COVID-19 pandemic contained information on "dos and don'ts" meant to prevent the virus from spreading. Yet, instructions were only part of the information employees wanted and needed during the pandemic (Orangefiery, 2020). They requested more in-depth information to help them comprehend and understand the situation and their management's decisions, especially because some of these decisions implied considerable changes for employees, which caused stress for many (Toscano and Zappalá, 2020). Thus, it was important to also provide information on what, when, where, why and how things were happening in connection to the crisis and what this meant regarding the working situation (Heide and Simonsson, 2019).

Information is a means to create knowledge and allow people to understand a situation. In challenging situations like crises or change, employees generally want to understand what is happening and why things were decided the way they were. In a change context, Sonenshein and Dholakia (2012) conceive understanding as part of meaning-making, where individuals try to explain occurrences through a broader system of meaning. By drawing on what they call a "strategy worldview," employees construct meaning as emanating from their management's strategy, which helps lend coherence to the situation "and allows them to understand why they must make adjustments" (Sonenshein and Dholakia, 2012, p. 3). The authors find that formal managerial communication can enhance employees' level of meaning-making through understanding and thereby show that what the organization's management says can have a significant impact on how employees interpret and perceive the situation (Heide and Simonsson, 2019).

The role of understanding derives from its possible influence on employees' acceptance of their management's decisions and their openness to the changes that result from these decisions. Van den Heuvel et al. (2009) show in a change context that understanding (as part of meaning-making) is positively related to employees' willingness to change. As research on public acceptance indicates, increased knowledge as well as understanding of a product or a new policy is accompanied by increased acceptance (e.g. Dolnicar and Hurlimann, 2011). In all, informational crisis communication, which includes the communication of factual information about the effects of the COVID-19 pandemic, governmental regulations affecting the organization, and the changes this implies for the organization and its workforce, should have helped employees construct meaning and an understanding of the situation, which fostered their acceptance and support of the decisions taken by their management. This leads to the first hypothesis:

H1. Satisfaction with factual corporate information enhances employees' acceptance of managerial decisions.

Yet, the information also needs to be communicated in an adequate manner. Transparency is considered a critical aspect of communication (Kim, 2018) that "promotes accountability,

\section{Employee support during the COVID-19 pandemic}

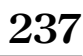


$\mathrm{JCOM}$ 25,3

collaboration, cooperation and commitment" (Jahansoozi, 2006, p. 11). Transparent communication has been defined as "an organization's communication to make available all legally releasable information to employees whether positive or negative in nature" (Men, 2014, p. 260). Rawlins (2009) differentiates different dimensions of organizational transparency as perceived by stakeholders. To be perceived as transparent, the communicated information first of all needs to display certain substantial characteristics like timeliness, completeness, accuracy and comprehensibility. These characteristics generate a sense of whether the information is substantially useful for stakeholders and their decision making. According to Heide and Simonsson (2020), especially in the acute phase of a crisis, the focus of internal communication must be on the provision of relevant, fast information through all available channels. A survey by Orangefiery (2020) conducted during the COVID-19 crisis revealed that employees want transparent, helpful, direct and clear communication from their management. Research in change communication furthermore shows that transparent communication helps to enhance openness during organizational change (Yue et al., 2019). Thus, we hypothesize that substantial characteristics of the information conveyed during the pandemic fostered the acceptance of managerial decisions.

H2. Receiving substantial information enhances employees' acceptance of managerial decisions.

Relational crisis communication and its effects. By means of relational crisis communication, organizations can, first of all, express regard or esteem to provide the resource that Foa and Foa (1980) termed status. Taking employees' needs and wants into account by listening to them and engaging in dialogue signals that they are cherished and esteemed stakeholders of the organization. Extant research confirms that two-way symmetrical communication implies an organization's willingness to listen and respond to the concerns and interests of its stakeholders, aims to build dialogue, promotes mutual understanding (Grunig, 1992; Men and Stacks, 2014) and fosters employees' perceived relationship with their organization (Kim, 2018).

Inviting employees to voice their needs and provide feedback is also a dimension of transparency, which Rawlins (2009) termed participation. According to Rawlins (2009), stakeholders must be invited to participate in order to identify the information the organization needs to make accurate decisions. Smidts et al. (2001) found that a communication climate where employees can participate in decision making and feel that they are taken seriously fosters identification with the organization. Men et al. (2020) furthermore showed that perceived organizational transparency is positively related to employees' identification with an organization. Identification is closely related to affective commitment, which constitutes an individual's emotional attachment to and identification with the organization (Meyer and Allen, 1991) [1]; it emphasizes the possible emotional connection that employees can have with their organization and comprises the development of psychological affinity and association with the organization, as well as the desire to remain a member of it (Allen and Meyer, 1990). Referring to transparency in general, Jahansoozi (2006) states that "transparency promotes accountability, collaboration, cooperation and commitment” (p. 11).

Thus, we hypothesize that employees respond to their organization's efforts to listen to them and ask for their feedback during the difficult pandemic situation-i.e. participationby providing a supportive emotional resource in the form of affective organizational commitment.

H3. Participation enhances affective organizational commitment.

Relational crisis communication is also a means to convey love, which in the working context is rather expressed as appreciation. In the context of external crisis communication, Coombs (2006) suggests, as part of the ingratiation response, to praise stakeholders and thank them 
for their help. This response strategy all the more applies internally. Crises demand a great deal from employees, who are usually the ones tasked with actively solving the situation (Heide and Simonsson, 2020). As Kahn (1990) pointed out, "You put energy where it will be appreciated” (p. 708). According to Danish and Usman (2010), employees' performance and organizational commitment increases when they feel valued and appreciated, and appreciation has been shown to relate to employees' enjoyment of their jobs (Strack et al., 2014). White (2017) found that receiving words of affirmation is the primary way employees feel appreciation in the workplace. In the case of the COVID-19 pandemic, Dirani et al. (2020) emphasize the importance of appreciation toward employees and recommend a platform to celebrate them. McGuinnes (2020) stresses the importance of putting employees first and showing gratitude for their dedication in order to strengthen their commitment.

Thus, we assume that the communication of appreciation was a powerful way to enhance the emotional connection between organization and employees - i.e. affective organizational commitment-during the COVID-19 pandemic. Therefore:

H4. Communicated appreciation enhances affective organizational commitment.

\section{The role of cognitive appraisal in affective commitment}

In line with the appraisal theory of emotion, studies have shown that emotional reactions tend to emerge from the cognitive appraisal of a situation (Butt and Choi, 2006; Roseman et al., 1990). During a crisis, appraisal of the situation becomes manifest in the acceptance of managerial decisions. This, in turn, should influence employees' emotional response, for example, their affective organizational commitment. The mediating role of affective commitment between the cognitive variable meaningfulness of work and employee engagement has been shown by Kaur and Mittal (2020), while Wanberg and Banas (2000) found a negative influence of acceptance to change on work irritation, i.e. the tendency to become angry, aggravated or annoyed. Drawing on appraisal theory and these previous empirical findings, we assume that employees who accepted their managers' decisions also felt more affectively committed to their organization. Hence:

H5. Employees' acceptance of organizational decisions enhances affective organizational commitment.

\section{Job engagement as a crucial resource provided by employees}

While employees' acceptance of managerial decisions and their emotional bond with their work organization-i.e. affective organizational commitment - are important resources for an organization during a crisis situation; it is employees' willingness to fully bring themselves into their work roles - i.e. engagement - which serves as a key resource that helps organizations mitigate negative economic consequences. Engagement is not a behavior, but rather a motivational and psychological state in which employees' hearts, minds and hands are bound to their work (Christian et al., 2011); it "consists of cognitive, emotional, and behavioral components that are associated with individual role performance" (Saks, 2006, p. 602). Specifically, engagement has been found to enhance job satisfaction (Biswas and Bhatnagar, 2013; Saks, 2006), task and job performance (Rich et al., 2010), organizational citizenship behavior (Saks, 2006; Yin, 2018) and employee advocacy (Kang and Sung, 2017; Shen and Jiang, 2019). "Engaged employees will advocate on behalf of their employing organizations and likely voluntarily help coworkers and go the extra mile to contribute to the organizational bottom line" (Shen and Jiang, 2019 , p. 44). Research furthermore shows that engagement has a negative influence on counterproductive work, burnout (Rich et al., 2010; Yin, 2018) and turnover intentions (Jiang and Shen, 2020). These behaviors, which are closely related to employee engagement, are highly relevant to an organization in mastering a crisis situation.

\section{Employee support during the COVID-19 pandemic}


$\mathrm{JCOM}$

25,3

But what exactly is employee engagement? In an early definition, Kahn (1990) referred to it as the "harnessing of organization members' selves to their work roles; in engagement, people employ and express themselves physically, cognitively, and emotionally during role performances" (p. 694). He identified three psychological conditions that are associated with engagement at work, namely meaningfulness, safety and availability (Kahn, 1990). Schaufeli et al. (2002) proposed another influential definition, regarding engagement as "a positive, fulfilling, work-related state of mind that is characterized by vigor, dedication, and absorption" (p. 74).

Acknowledging that organizational members have multiple roles in their organization (Kahn, 1990), Saks (2006) differentiated between the two most dominant ones, namely "their work role and their role as a member of an organization" (Saks, 2006, p. 604). The former is termed job engagement, the latter organizational engagement. Job engagement refers to the degree of attentiveness and absorption in the performance of a job role. Attentiveness refers to the cognitive availability and the amount of time individuals thinks about their role (Rothbard, 2001). Absorption "means being engrossed in a role and refers to the intensity of one's focus on a role" (Rothbard, 2001, p. 656) and can be strongly under attack during a crisis situation (Chanana and Sangeeta, 2020). Organizational engagement is defined as a "dynamic changeable psychological state" that links employees to their organizations and manifests in organization member role performances (Welch, 2011, p. 337). Both, job and organizational engagement, can be influenced by internal communication (Welch, 2011). For many employees, the COVID-19 pandemic has led to radical changes in the workplace and work routines, causing very individual and personal difficulties and uncertainties. As "personality and affect are very much individual-level constructs" (Pugh and Dietz, 2008, p. 46), keeping up employees' individual work role performance is a major concern of organizations during a crisis (Chanana and Sangeeta, 2020; Mani and Mishra, 2020). Importantly, organizations make every effort to minimize the risk of low job engagement or even job disengagement, i.e. the active removal from the job role (Kahn, 1990), which is assumed to yield dissatisfaction, disinterestedness, poor work performance, counterproductive work behavior and uncertainty (Rastogi et al., 2018). Therefore, the present study focuses on job engagement rather than organizational engagement.

A growing number of scholars have recognized the role of internal communication in fostering engaged individuals (Men and Bowen, 2017). Lemon (2019) points out that engagement starts with dialogue. Several studies provide evidence of a positive effect of different communication strategies (e.g. transparent communication, symmetrical communication, communication through different channels) to create an engaged workforce (Jiang and Men, 2017; Jiang and Shen, 2020; Men, 2014; Men and Stacks, 2014). Yet, instead of assuming a direct influence of internal crisis communication on employees' job engagement during the crisis situation, we hypothesize that this effect is mediated through cognitions (acceptance) and emotions (affective commitment). That is, employees are attentive and absorbed in their job roles because they accept their management's decisions and are affectively committed to their work organization.

A meta-analysis by Meyer et al. (2002) supports that affective commitment includes a wide range of outcomes such as engagement, involvement and satisfaction. In a crisis situation in particular, affectively committed employees who feel emotionally attached to their work organization and want to remain part of it until they retire should be more likely than their uncommitted colleagues to engage themselves fully in their jobs to help their organization master the crisis. Affectively committed employees also see a great deal of personal meaning in working in their organizations, which should motivate them to be more attentive and absorbed in the performance of their jobs (e.g. Kahn, 1990; May et al., 2004). Empirical research in a non-crisis context demonstrates the influence of affective commitment on employee engagement (Shuck et al., 2011). Asif et al. (2019) established the role of affective 
commitment as a mediator between ethical leadership and work engagement in a study on public sector employees in China. Affective commitment has also been shown to mediate the influence of meaningfulness of work (Kaur and Mittal, 2020) and perceived career support from the employer (Poon, 2013) on work engagement. Based on the above reasoning and extant empirical evidence, we hypothesize:

H6. Affective organizational commitment enhances employees' job engagement.

Literature on change and change management furthermore hints at the influence of cognitions, specifically the acceptance of managerial decisions, on job engagement. Weber and Manning (2001), for example, argue that understanding the change is important for change implementation. The influence of acceptance on positive work attitudes during an organizational change was shown by Sagie and Koslowsky (1996), and Peng and Lee (2019) confirmed that acceptance of managerial decisions (as part of the larger construct work ethic) has a positive influence on whether employees support their organization's strategy. In their study on the effects of meaning-making during change, Van den Heuvel et al. (2009) showed that employees' willingness to change is positively correlated with work engagement. Willingness to change, which is part of the acceptance construct, is an attitudinal variable that is said to result in employee efforts to support the change process (Metselaar, 1997, cited in Van den Heuvel et al., 2009). Based on these findings, we expect that employees who accepted their management's decisions during the COVID-19 pandemic were more engaged in their jobs during the crisis compared to their colleagues who were not accepting of their management's decisions. Thus, the last hypothesis is as follows:

H7. Employees' acceptance of managerial decisions during the crisis enhances employees' job engagement.

In all, the system of seven hypotheses forms our conceptual model (see Figure 1). The empirical research to test the model will be described next.

\section{Empirical research}

\section{Procedure}

To test the hypothesized model, an online survey among Austrian employees was conducted from April 6 to 18, 2020, three to four weeks after the Austrian government ordered a countrywide shutdown on March 16. For recruiting participants, the authors used the assistance of the global market research service provider, Dynata. From the pool of registered panel

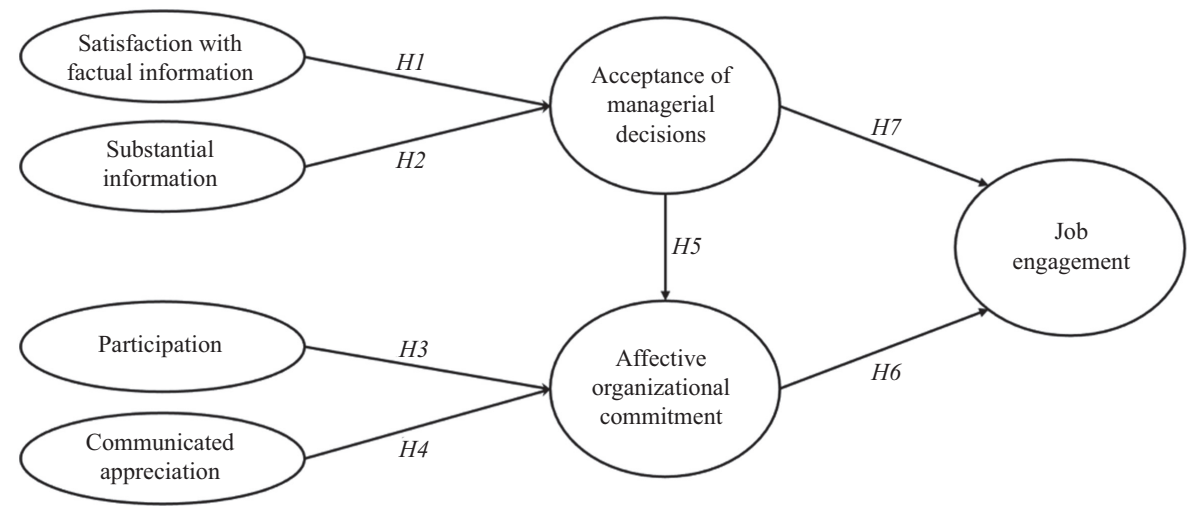

Figure 1. Conceptual model 
$\mathrm{JCOM}$ 25,3

members in Austria, Dynata preselected and invited panelists who were employed full time with an organization having a minimum of 10 employees and who were employed by the same organization before and after the shutdown. In total, 1,068 people fulfilled these criteria and answered the online survey. After incomplete cases were excluded, we accomplished a final sample size of 1,033 respondents to be analyzed in the present study.

\section{Sample}

Respondents were $55.6 \%$ female, and the average age was 40.7 years ( $\mathrm{SD}=11.3$ ). Asked for their highest educational qualification, $31.1 \%$ stated they had a high school diploma; $27.8 \%$ held a university degree; $26.7 \%$ had completed an apprenticeship; $10.8 \%$ had an intermediate educational qualification; and 3.5\% stated they only had compulsory schooling. The respondents were employed across a variety of industries and sectors (health care and social assistance: $15.0 \%$; manufacturing: $14.3 \%$; public administration/ service: $12.3 \%$; retail trade: $9.8 \%$; finance and insurance: $6.1 \%$; media, information, and communication: $5.4 \%$; transportation and logistics: $5.1 \%$; construction: $4.2 \%$; accommodation and food services: $3.6 \%$; utilities: $2.6 \%$; and other sectors: $21.6 \%$ ) and were nearly evenly distributed across four company sizes (10-49 employees: $23.3 \%$; 50 to 249 employees: $24.7 \%$; 250 to 1,000 employees: $25.8 \%$; and more than 1,000 employees: $26.2 \%$ ). A position with managerial responsibility was held by $25.4 \%$ of the employees in the sample. Organizational tenure was distributed as follows: $11.0 \%$ were employed with their organization for less than one year, $12.4 \%$ one to two years, $21.4 \%$ three to five years, $18.3 \%$ six to 10 years, and $36.9 \%$ for more than 10 years. Concerning crisis-induced alterations in their place of work, $38.0 \%$ of the respondents stated that they worked fully from home; $36.4 \%$ worked at their regular workplace, and $25.6 \%$ shifted between their regular place of work and home.

\section{Measurements}

The questionnaire design adopted established scales from previous research wherever those were available. New measurements were created where literature did not provide suitable measurement instruments. For consistency, all items were rated on five-point scales ranging from 1 = "does not apply at all" to 5 = "applies fully," except for satisfaction with factual corporate information where the scale ranged from $1=$ "not at all satisfied" to $5=$ "very satisfied." Detailed information on the wording of questions as well as scale endpoints and items can be found in Table 1. Translation of the items from established scales employed iterative forward and backward translation with the help of a native English speaker also proficient in German.

To measure employees' satisfaction with factual corporate information concerning the general impacts and demands brought about by the COVID-19 pandemic, we drew on the sub-dimension "corporate information" from the communication satisfaction questionnaire of Downs and Hazen (1977). Because items needed to reflect the current situation, they were adapted or newly developed by the researchers. Substantial information and participation were measured with the corresponding items from the "transparency efforts" scale by Rawlins (2009). Because no scale yet exists to measure communicated appreciation, the authors developed three items to measure this construct. For the measurement of the acceptance of managerial decisions, we drew on the organizational change literature. Selected items for openness to change (Miller et al., 1994) and outcome fairness (Daly and Geyer, 1994) were adapted and complemented in order to assess employees' acceptance in the crisis context. Affective organizational commitment was measured using five items from the eightitem scale by Allen and Meyer (1990). The negative wording of two of the items was changed to positive to avoid a two-factor solution, as suggested Merritt (2012). To measure job engagement, we used the scale developed by Saks (2006), but omitted the negatively worded 


\begin{tabular}{ll}
\hline Construct/Items & SL \\
\hline Satisfaction with factual corporate information & \\
[How satisfied are you with the information you have received from your & \\
employer on the following topics in the current Corona crisis? (Scale from 1 & \\
"not at all satisfied" to 5 “very satisfied")] & 0.79 \\
The effects of the Corona crisis on our organization & 0.78 \\
The effects of the Corona crisis on the area in which I work & 0.76 \\
Official decisions and orders that affect the organization & 0.70 \\
Dos and Don'ts in the Corona crisis, i.e. what you can and cannot do & 0.85 \\
New demands on employees & 0.85 \\
Changes within the organization &
\end{tabular}

\section{Substantial information}

For employees like me the information that my employer is providing in the current Corona crisis is ... (Scale from 1 "does not apply at all" to 5 "applies fully")

... relevant

... timely

... complete

... understandable

... accurate

... reliable

... comparable

\section{Participation}

My employer ... (Scale from 1 "does not apply at all" to 5 "applies fully")

... asks for feedback from people like me about the quality of its information

... involves people like me to help identify the information I need

... provides detailed information to people like me

... makes it easy to find the information people like me need

... asks the opinions of people like me before making decisions

... takes the time with people like me to understand what we need

\section{Communicated appreciation}

How much do the following statements apply? (Scale from 1 "does not apply at all" to 5 "applies fully")

My employer thanks employees like me for their commitment during the Corona crisis

During this time, employees like me are highly valued by management

It is openly communicated that the work of employees like me is important

\section{Acceptance of managerial decisions}

How much do the following statements apply? (Scale from 1 "does not apply at all" to 5 "applies fully")

Our management quite rightly made its decisions

Our management had every right to make decisions as they were made

I accept the decisions our management made during this crisis

I actively support the decisions our management made during this crisis

I am open to the changes that will result in my work due to the Corona crisis

\section{Affective organizational commitment}

How connected do you currently feel to your employer? (Scale from 1 "does not apply at all" to 5 "applies fully")

I feel a strong sense of belonging to my organization

I feel emotionally attached to this organization

This organization has a great deal of personal meaning for me

I would be very happy to spend the rest of my career with this organization

I really feel as if this organization's problems are my own
SL

$\begin{array}{ccc}\alpha & \text { CR } & \text { AVE } \\ 0.92 & 0.91 & 0.63\end{array}$

0.79

0.78

0.76

0.70

0.85

\section{$0.92 \quad 0.92 \quad 0.66$}

0.75

0.81

0.84

0.72

0.86

0.89

deleted

Employee support during the COVID-19

pandemic
0.80

0.83

0.83

0.81

0.73

0.86

$\begin{array}{lll}0.93 & 0.94 & 0.83\end{array}$

0.94

0.89

$\begin{array}{lll}0.92 & 0.92 & 0.69\end{array}$

0.85

0.83

0.89

0.89

0.67

$\begin{array}{lll}0.91 & 0.90 & 0.70\end{array}$ $\begin{array}{lll}0.93 & 0.92 \quad 0.66\end{array}$ 
$\mathrm{JCOM}$ 25,3

\section{4}

Table 1

\begin{tabular}{lcccc}
\hline Construct/Items & SL & $\alpha$ & CR & AVE \\
\hline Job engagement & & 0.80 & 0.81 & 0.59 \\
How are you doing with your work at the moment? (Scale from 1 "does not & & & & \\
apply at al" to 5 "applies fully") & & & & \\
At the moment, I really "throw" myself into my job & 0.67 & & & \\
I am totally into my job & 0.82 & & & \\
I am highly engaged in this job & 0.80 & & & \\
Sometimes I am so into my job that I lose track of time & deleted & & &
\end{tabular}

Note(s): SL $=$ standardized loading; $\alpha=$ Cronbach's alpha; $\mathrm{CR}=$ composite reliability; AVE $=$ average variance extracted

item. We also eliminated references to the "all consuming" nature of the job and added "at the moment" to one of the items to capture the current state of job engagement during the pandemic.

\section{Results}

In accordance with Kline (1998), we executed a two-step structural equation modeling (SEM) analysis using AMOS 26 software under maximum likelihood estimation. First, the measurement model was tested based on the a priori theoretical conceptualizations of the constructs. Second, we tested the structural model and the hypothesized relationships between the variables. In both steps, the cutoff criteria (CFI/TLI $\geq 0.95$, RMSEA $<0.06$, SRMR < 0.08) proposed by Hu and Bentler (1999) served as a reference point for the evaluation of the data-model fit.

\section{Measurement model}

After deleting a few indicators that showed unsatisfactory factor loadings during initial confirmatory factor analysis (see Table 1), the final measurement model showed a good model-data fit $\left(\chi^{2}=1308.129[p<0.001]\right.$; df $=466$; CFI $=0.971$; TLI $=0.967$; RMSEA $=0.042$ [90\% CI: 0.039, 0.045], SRMR $=0.036$ ). Standardized factor loadings are reported in Table 1; they exceeded in all cases the minimum threshold of 0.6 and in most cases the ideal threshold of 0.7 (Chin, 1998). Strong reliability and convergent validity were indicated for all constructs: Cronbach's alpha scores ranged from 0.80 to 0.93 and composite reliabilities from 0.81 to 0.94 , both of which exceeded the minimum threshold of 0.70 , and the AVE (average variance extracted) scores were for all constructs above the cutoff criterium (>0.50) for convergent validity (Hair et al., 2009). For a rigorous assessment of discriminant validity, we applied two techniques: the common Fornell-Larcker criterion (Fornell and Larcker, 1981) and the more recently proposed heterotrait-monotrait (HTMT) ratio of correlations (Henseler et al., 2015; Voorhees et al., 2016). The Fornell-Larcker criterion was fulfilled by all dyads of constructs with one exception (see Table 2). For the construct participation, the square root of its AVE was less than its correlation with the construct communicated appreciation, which indicates some concern about discriminant validity. However, Voorhees et al. (2016) showed that conditions where focal correlations and average factor loading values are comparable (which is true for these two constructs) can result in arbitrary violations of the Fornell-Larcker criterion. Since the HTMT ratio for these two constructs $\left(\mathrm{HTMT}_{\text {[participation,appreciation] }}=0.80\right.$ ) and all other dyads was below the conservative threshold of 0.85 , we are confident that discriminant validity is achieved across all measurements. Overall, the constructs exhibit sound measurement properties. 


\begin{tabular}{|c|c|c|c|c|c|c|c|c|}
\hline & (1) & (2) & (3) & (4) & (5) & (6) & (7) & yee \\
\hline Satis & 0.79 & 0.77 & 0.66 & 0.63 & 0.71 & 0.56 & 0.43 & COVID-19 \\
\hline Sul & 0.77 & 0.81 & 0.73 & 0.65 & 6 & 22 & 0.46 & \\
\hline$D_{0 x}$ & 0.70 & 0.75 & 0.81 & 0.80 & 0.64 & 0.68 & 0.46 & \\
\hline ation & 0.6 & 0.65 & 0.82 & 0.91 & 0.63 & 0. & 0.50 & \\
\hline decisions & 0.7 & 0.75 & 0.66 & 0.62 & 0.83 & 0.66 & 0.50 & \\
\hline onal commitment & 0.59 & 0.63 & 0.71 & 0.74 & 0.67 & 0.84 & 0.64 & 24 \\
\hline 7) Job engagement & 0.43 & 0.45 & 0.47 & 0.49 & 0.49 & 0.65 & 0.77 & \\
\hline \multicolumn{8}{|c|}{$\begin{array}{l}\text { Note(s): Diagonal and italic elements are the square roots of the AVE (average variance extracted). Below the } \\
\text { diagonal elements are the correlations between the constructs values, and above the diagonal elements are the } \\
\text { HTMT (heterotrait-monotrait ratio of correlations) values. All bivariate correlations are significant at the } \\
p<0.001 \text {-level }\end{array}$} & $\begin{array}{r}\text { T } \\
\text { Discriminant } \\
\text { of } \mathrm{cc} \\
\text { measu }\end{array}$ \\
\hline
\end{tabular}

\section{Structural model}

Having established satisfactory measurement model fit, the hypothesized structural model was evaluated. Based on extant literature (e.g. Yue et al., 2019), age, gender, organizational tenure, position and company size could potentially affect the endogenous variables and were included as controls in the structural model. Additionally, we assumed that whether an employee was working from home or at the regular work place could possibly impact the endogenous variables (especially their job engagement and acceptance of managerial decisions). Hence, crisis-induced alterations of the work place were included as a further control variable in the structural model. The structural model based on our hypotheses (see Figure 1) demonstrated good fit $\left(\chi^{2}=1614.665[p<0.001]\right.$; df $=630$; CFI = 0.967; TLI = 0.961; RMSEA $=0.039$ [90\% CI: 0.037, 0.041], SRMR $=0.036$; AIC $=1914.665 ; \mathrm{BIC}=2655.698$ ), and all hypothesized relationships were significant $(p<0.01)$.

To account for possible additional relationships between the variables that go beyond our hypotheses, we tested two alternative models. The first alternative model included additional paths from informational crisis communication (satisfaction with factual corporate information, substantial information) to affective commitment, as well as from relational crisis communication (participation, communicated appreciation) to acceptance of managerial decisions. Since one of these additional paths reached significance, and the overall model fit slightly improved as indicated by lower values for the Akaike (AIC) and Bayes (BIC) information criterion $\left(\chi^{2}=1584.661[p<0.001]\right.$; df $=626$; CFI $=0.967$; $\mathrm{TLI}=0.961 ; \mathrm{RMSEA}=0.039$ [90\% CI: 0.036, 0.041], SRMR $=0.034 ; \mathrm{AIC}=1892.661$; $\mathrm{BIC}=2,653.455$ ), this model was kept as the final model for hypotheses testing (see Figure 2). The second alternative model, which also included the direct paths from the exogenous variables to job engagement, resulted in no further fit improvement $\left(\chi^{2}=1583.529[p<0.001]\right.$; $\mathrm{df}=622 ; \mathrm{CFI}=0.967 ; \mathrm{TLI}=0.961 ; \mathrm{RMSEA}=0.039[90 \% \mathrm{CI}: 0.036,0.041]$, SRMR $=0.034$; $\mathrm{AIC}=1899.529 ; \mathrm{BIC}=2680.084)$, and none of the additional paths reached significance $(p>0.10)$.

\section{Hypotheses testing}

The data revealed a positive relationship between satisfaction with factual corporate information and employees' acceptance of managerial decisions $(\beta=0.27, p<0.001)$, supporting H1. As assumed in H2, substantial information had a significant positive effect on employees' acceptance of managerial decisions $(\beta=0.41, p<0.001)$. In addition to these hypothesized effects, acceptance was positively affected by communicated appreciation $(\beta=0.16, p<0.001)$, but not by participation $(\beta=0.02, p=0.733)$. The $R^{2}$-value for employees' acceptance of managerial decisions was 0.62 . 


\section{JCOM \\ 25,3}

\section{6}

Figure 2.

Structural model

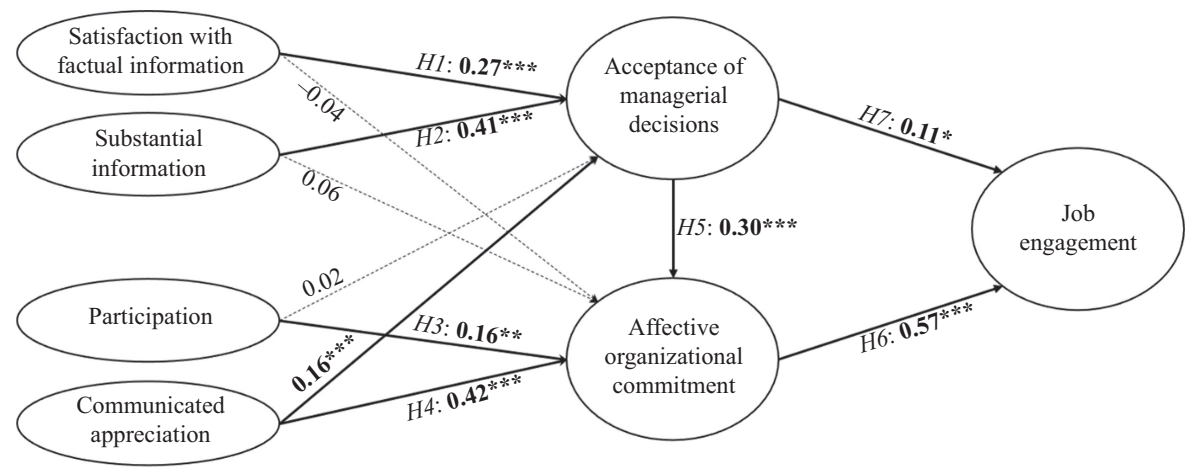

Note(s): It was controlled for possible effects of age, gender, organizational tenure, position, company size, and crisis-induced alterations of work place (home vs. regular) on the endogenous variables; $\chi^{2}=1614.665[p<0.001]$; $\mathrm{df}=630$; CFI $=0.967$; TLI $=0.961$; RMSEA $=0.039$ [90\% CI: 0.037, 0.041], SRMR $=0.036$; dashed arrows represent non-significant $(p>0.10)$ path coefficients, ${ }^{* * *} p<0.001 ; * * p<0.01 ;{ }^{*} p<0.05$

In support of $\mathrm{H} 3$, participation had a positive effect on affective commitment $(\beta=0.16$, $p<0.01$ ). Furthermore, communicated appreciation positively influenced affective commitment $(\beta=0.42, p<0.001)$, thereby supporting H4. None of the informational aspects of internal crisis communication (satisfaction with factual corporate information: $\beta=-0.04, p=0.32$; substantial information: $\beta=0.06, p=0.23$ ) had a significant direct effect on affective commitment. However, as proposed in H5, employees' acceptance of managerial decisions positively influenced affective commitment $(\beta=0.30, p<0.001)$. The $R^{2}$-value for affective commitment was 0.65 .

H6 was fully supported by the data as affective commitment showed a significant effect on employees' job engagement $(\beta=0.57, p<0.001)$. Also, in line with $\mathrm{H} 7$, the assumed effect of employees' acceptance of managerial decision on job engagement reached significance $(\beta=0.11, p<0.05)$, although it was comparatively weak. For job engagement, the explained variance was $R^{2}=0.44$.

To finally assess the impact of the informational and relational aspects of internal crisis communication on employees' job engagement, the total indirect effects mediated through employees' acceptance of managerial decisions and affective commitment were gauged by a bootstrapping analysis with $N=2000$ draws. For informational internal crisis communication, the results indicated a significant indirect effect of substantial information ( $\beta=0.13, p<0.001,95 \%$ CI [0.06 to 0.19]), but not of satisfaction with factual corporate information ( $\beta=0.04, p=0.128,95 \% \mathrm{CI}[-0.01$ to 0.10$]$ ), on job engagement. Both aspects of relational crisis communication had a significant indirect effect on job engagement, although the indirect effect of communicated appreciation $(\beta=0.20, p<0.001,95 \%$ CI [ 0.15 to 0.25$])$ was more meaningful than that of participation $(\beta=0.07, p<0.05,95 \%$ CI [0.01 to 0.13]).

\section{Discussion}

A health crisis such as the COVID-19 pandemic that struck globally at the beginning of the 2020 s presents an exceptional situation for organizations. Whether they experience a threat to their existence or, in fact, more work because of the business they are in, effectively managing and mastering this critical situation highly depends on the cooperation of employees. The research presented here underscores the important role of social resource 
exchanges between an organization and its employees during such an uncertain situation, as argued in social exchange theory (e.g. Blau, 1964). We confirm the notion that the provision of various organizational resources increases the willingness of employees to give something back (Cropanzano and Mitchell, 2005). Specifically, the non-economic social resources information, status and love (Foa and Foa, 1980), which can be provided via internal crisis communication, have the capacity to engender supportive responses in employees, yet to a different extent.

The results show that an informational communication strategy, which includes not only instructional information but also information about the effects of the crisis on the organization and employees' work situation, is important during the acute phase of the crisis as it significantly fosters employees' acceptance of managerial decisions. Importantly, the information also needs to be substantial, i.e. relevant, timely, complete, understandable, accurate and reliable (Rawlins, 2009). Thus, we confirm the importance of instructional information (Heide and Simonsson, 2020) that is conveyed in a transparent manner (Rawlins, 2009) to reach employees at a cognitive level. Especially during a health crisis when decisions often need to be made quickly, employees' acceptance of organizational measures is extremely important in engendering their further support in the form of job engagement, as shown by the data. Conversely, poor informational crisis communication may entail several negative outcomes such as resistance, decreased engagement, counter-productive work, burnout (Rich et al., 2010; Yin, 2018) and higher turnover intentions (Jiang and Shen, 2020).

While informational crisis communication leads to cognitive responses, it does not enhance employees' affective organizational commitment directly. Strengthening the emotional bond with employees rather requires a relational communication strategy. First, this strategy implies symmetrical communication aiming at dialogue and mutual understanding (Grunig, 1992; Men and Stacks, 2014), which Rawlins (2009) termed participation. Previous research in internal communication has already shown that symmetrical communication helps foster employee engagement (e.g. Kang and Sung, 2017). We confirm this positive influence on job engagement mediated by affective commitment. Second, our data suggest that expressing appreciation may be even more important than participation, at least in the specific context of this research. The strong influence of appreciation, not only on affective commitment but to some extent on the acceptance of managerial decisions as well, can be explained by the particularly demanding situation of employees. They had to very quickly adapt their work practices to the new requirements and work under personal and job-related uncertainty and the risk of becoming infected. Thus, as Coombs (2006) suggests for crisis communication with external stakeholders, providing the resource love by showing appreciation is especially important to win employees' commitment and support. Beside these direct effects of a relational communication approach, employees' affective commitment is also positively affected by informational communication through enhanced acceptance of managerial decisions, which has a positive effect on commitment. This corresponds with previous findings on the positive effect of transparent communication on employee-organization relationships (e.g. Lee and Li, 2020; Men and Stacks, 2014). The separate examination of informational aspects, i.e. substantial information, and relational aspects, i.e. participation, of transparent internal communication as done in this study, allows for a more nuanced account of direct and indirect effects on employees' emotional bond with an organization during a crisis.

Overall, of the four aspects of internal crisis communication, communicated appreciation emerged as the strongest driver of job engagement in an acute and particularly demanding crisis situation.

\section{Implications for theory and practice}

The study contributes to the growing body of research on internal crisis communication in several ways. By looking at the relationship between organizations and their employees 
$\mathrm{JCOM}$

25,3

248

during a crisis through the lens of the social exchange theory, we shed light on the role of communication in conveying several non-economic resources to indirectly foster employees' job engagement. Aligning the resources information, status and love (Foa and Foa, 1980) with informational and relational crisis communication strategies, we provide a novel application of social exchange theory to internal communication during an organizational crisis. This helps to confirm previous notions that instructional crisis information and discussion (Heide and Simonsson, 2019, 2020) are essential during the acute phase of a crisis and that participatory communication fosters organization-employee relationships (Men and Stacks, 2014). Drawing on social exchange theory furthermore helps identify the resource love, which can be communicated by means of appreciative communication. This resource has a strong influence on affective organizational commitment, which has been considered the most important driver of positive organizational outcomes, including job engagement (e.g. Meyer and Maltin, 2010; Meyer et al., 2002; Mowday et al., 1982; Rhoades et al., 2001), as was confirmed by this research. This shows that social exchange theory (e.g. Blau, 1964) and resource theory (Foa and Foa, 1980) provide a profound theoretical basis to explain the organization-employee relationship during a crisis.

The study furthermore contributes to the literature by testing the effects of internal crisis communication on job engagement, which is considered a key element for organizational success and competitiveness (Saks and Gruman, 2014) but is under-researched in the crisis context. Maintaining or even strengthening employees' attentiveness and absorption in the performance of their work roles (Saks, 2006) is essential to reach the overarching goal during a crisis, which is to collaborate and function properly in order to mitigate negative economic consequences (Heide and Simonsson, 2019). Extant research confirmed the importance of transparent and symmetrical communication as well as relevant channels to stimulate engagement (Jiang and Men, 2017; Jiang and Shen, 2020; Men, 2014; Men and Stacks, 2014). However, stimulating job engagement in a crisis context also requires taking the specific situation closely into account. The COVID-19 pandemic, because of its novelty and severity, raised many questions and uncertainties, especially (but not only) during its early stages. Thus, in such a situation, aside from the extremely important relational communication practices, informational communication was also of some relevance to enhance job engagement via employees' acceptance of management's decisions.

Another contribution, but also a limitation (see below), of this research is the test of the theoretical model in this real-world crisis situation. Oftentimes, research on internal crisis communication is conducted using fictitious crisis scenarios (e.g. Kim, 2018). The COVID-19 pandemic and the organizational crises it inflicted allowed for the collection of real-world data, which enhances the external validity of the findings. The research furthermore helps to explain internal crisis communication during a global health crisis in which organizations were the victims of external events and therefore not responsible for the crisis (Coombs, 2015). However, because of the high-risk situation, they bore great responsibility not only for mitigating harm to the business but also, importantly, for protecting their employees not only from the virus, but from negative effects of the changed working conditions.

The findings also have important implications for the practice of internal crisis communication. Ensuring appropriate crisis communication that addresses employees on cognitive and affective levels should be a priority in the acute phase of a crisis in order to prevent lack of acceptance of the decisions made, lack of affective commitment and disengagement (e.g. Wollard, 2011). Deficient crisis communication can severely compromise employee support (Frandsen and Johansen, 2011) and possibly lead to negative communication behavior regarding the organization's crisis management (Shen and Jiang, 2019), which in turn can damage the organization's reputation. Judging from the results of this study, such negative outcomes can be mitigated by an adequate informational and relational crisis communication strategy. The findings imply that even if economic resources 
are scarce, employee support can still be upheld by means of social resources such as information, status and love (Foa and Foa, 1980).

The results furthermore imply that reliance on merely an informational communication strategy can help create acceptance of decisions, but it cannot support employees on an emotional level. Since a crisis, a global pandemic in particular, is often associated with a high level of personal and job-related uncertainty, communication practices that address the emotional state of employees are needed. This includes showing appreciation, but also practicing a participative leadership style. Some authors suggest that, especially at the beginning of a crisis, management must demonstrate control and determination in the uncertain situation (Seeger et al., 2003). However, such an authoritarian approach should be accompanied and quickly replaced by a participative and appreciative one to promote commitment and, ultimately, job engagement.

Signals of appreciation should come early in the crisis, preferably from top management, because the most memorable recognition comes from a senior leader or CEO (Mann and Dvorak, 2016). Middle managers play an important role, too, especially in facilitating communication between senior management and employees (Peters, 1988) and in implementing participatory communication efforts, which is important in times of crisis when uncertainty prevails and rumors can spread quickly. Yet, "the professional communications function, along with the human resources function, should be able to take overall responsibility and support leaders in this effort" (Heide and Simonsson, 2019, p. 50). Leader support involves providing middle managers with messages and materials through separate channels that facilitate their communication with their team. It can also mean giving instructions on how to conduct participatory communication effectively by means of digital communication tools, or how to rebut false rumors that may have spread. Thus, internal communication professionals must act as coaches for managers and enablers of leadership communication, over and above communicating themselves.

\section{Limitations and suggestions for further research}

The results of this research must be interpreted in light of several limitations. The data were collected in April 2020 at the beginning of organizational crises caused by the COVID-19 pandemic in Austria. While using a real case is advantageous for external validity, the peculiarities of this chosen crisis situation in terms of type, scale, timepoint and location of data collection limit the generalizability of the findings to other crisis situations and regions. The COVID-19 pandemic was a health crisis of massive proportions that caused "operational disruption from disasters" (Coombs, 2015, p. 67) in many organizations. Thus, the findings are primarily relevant for this type of organizational victim crisis. The point in time, namely three to four weeks into the first shutdown, can be considered another limitation. At this stage, uncertainty was high, and companies were still trying to find the best way to organize themselves in this novel situation. While informational communication and communicating appreciation was particularly important at that stage, we can assume that, at a later stage, actively including employees through participation may have become even more important. The location of data collection, Austria, also has to be considered when interpreting the findings. The first shutdown, which led to a standstill of public life and requested employees to work from home wherever possible, was ordered rather quickly by the Austrian government (Pollak et al., 2020). The government presented a very broad set of measures, primarily to ensure corporate liquidity and compensate costs, aimed primarily at those companies that suffered sales losses due to regulatory closures and impairments. In addition, a short-time work model was introduced, which aimed at helping curb the rise in unemployment. Problem awareness in society was rather high, which was partly due to the proximity to neighboring Italy, where the pandemic was raging (Czypionka et al., 2020).
Employee
support during
the COVID-19
pandemic

249 
$\mathrm{JCOM}$ 25,3

These circumstances may have led to a somewhat less dramatic perception of the situation by Austrian employees at the time of the survey compared to other countries where the governments provided less support and where infection rates were higher. This limits the generalizability of the findings to other economic and cultural environments.

The study also has methodological limitations. While causal relationships were assumed based on theory and previous empirical research, a rigorous test of causality would require a longitudinal or experimental research design. In light of this limitation, using experimental research seems a meaningful next step to replicating the present findings. The study furthermore relied on self-report data collected from a single source, namely, by means of a survey from the perspective of employees. Although a check of common method variance using Harman's single factor test (Fuller et al., 2016) did not imply an issue, future research can broaden the basis of data sources. To provide a more comprehensive understanding of how internal crisis communication influences employees' supportive responses, a triangulated approach incorporating multiple methods, such as in-depth interviews, focus groups and participant observation, aside from a survey can provide more in-depth and valid explanations. Another methodological limitation is the adaptation of some established scales to the crisis situation and their harmonization regarding scale length and endpoints. While this enhanced the fit and simplicity of the survey instrument, it caused some deviations from the original scales.

The research focused on the role of information, status and love as organizational resources, while neglecting the role and effects of money, goods and services (Foa and Foa, 1980). Thus, we cannot clarify the differential effect of the three non-economic resources in relation to economic resources on cognitive and affective responses and job engagement during an organizational crisis. Investigating this is the task of future research. The present study furthermore focused on specific cognitive and affective responses. While the variances explained were rather high, there are certainly other factors that potentially shape the overall relationship of internal crisis communication and job engagement. As perceptions of uncertainty may differ, personal or job-related uncertainty may function as moderating variables on the effects of communication types (e.g. Asfaw and Chang, 2019). Especially during an early stage, when the development of the crisis is still unclear (Coombs, 2015), personal or job-related uncertainty could be an important moderating variable for employees' need for information. Uncertainty reduction theory can help explain how individuals try to diminish uncertainty during an unknown situation by obtaining more information to reduce their concerns (Hogg and Belavadi, 2017).

The present study contributes to research on the role of specific crisis communication strategies during an unclear situation in which maintaining employees' attentiveness and absorption in their jobs is of major concern to organizations. To obtain a more nuanced understanding of the social exchange process in general with regard to job engagement (Kahn, 1990; Saks, 2006) and job disengagement (Wollard, 2011), applying a qualitative research approach will be a fruitful avenue for further research.

\section{Note}

1. Mayer and Allen (1991) differentiate three dimensions of commitment: the desire to remain with the organization (affective commitment), the obligation to stay (normative commitment) and the perceived cost of leaving (continuance commitment). In this study, we focus on affective commitment because this dimension of the construct is particularly reciprocated by employees in return for their organization's support (Rhoades et al., 2001).

\section{References}

Absolventa (2020), "Kurzarbeit: Auswirkungen aufs Gehalt", available at: https://www.absolventa.de/ karriereguide/arbeitsentgelt/kurzarbeit-2-auswirkungen-auf-das-gehalt (accessed 10 January 2021). 
Allen, N.J. and Meyer, J.P. (1990), "The measurement and antecedents of affective, continuance and normative commitment to the organization", Journal of Occupational Psychology, Vol. 63 No. 1, pp. 1-18.

Asfaw, A.G. and Chang, C.-C. (2019), "The association between job insecurity and engagement of employees at work", Journal of Workplace Behavioral Health, Vol. 34 No. 2, pp. 96-110.

Asif, M., Qing, M., Hwang, J. and Shi, H. (2019), "Ethical leadership, affective commitment, work engagement, and creativity: testing a multiple mediation approach”, Sustainability, Vol. 11 No. 16, pp. 1-16.

Biswas, S. and Bhatnagar, J. (2013), "Mediator analysis of employee engagement: role of perceived organizational support, P-O fit, organizational commitment and job satisfaction", Vikalpa, Vol. 38 No. 1, pp. 27-40.

Blau, P.M. (1964), Exchange and Power in Social Life, John Wiley, New York, NY.

Bruning, S. and Ledingham, J. (1999), "Relationships between organizations and publics: development of a multi-dimensional organization-public relationship scale", Public Relations Review, Vol. 25 No. 2, pp. 157-170.

Butt, A.N. and Choi, J.N. (2006), "The effects of cognitive appraisal and emotion on social motive and negotiation behavior: the critical role of agency of negotiator emotion”, Human Performance, Vol. 19 No. 4, pp. 305-325.

Chanana, N. and Sangeeta (2020), "Employee engagement practices during COVID-19 lockdown", Journal of Public Affairs. doi: 10.1002/pa.2508.

Chin, W.W. (1998), “Commentary: issues and opinion on structural equation modeling”, MIS Quarterly, Vol. 22 No. 1, pp. vii-xvi.

Christian, M., Garza, A. and Slauther, J. (2011), "Work engagement: a quantitative review and test of its relations with task and contextual performance", Personnel Psychology, Vol. 67 No. 1, pp. 89-136.

Coombs, W.T. (2006), "The protective powers of crisis response strategies", Journal of Promotion Management, Vol. 12 Nos 3-4, pp. 241-260.

Coombs, W.T. (2015), Ongoing Crisis Communication: Planning, Managing, and Responding, Sage Publications, Thousand Oaks, CA.

Cropanzano, R. and Mitchell, M.S. (2005), "Social exchange theory: an interdisciplinary review", Journal of Management, Vol. 31 No. 6, pp. 874-900.

Cropanzano, R., Anthony, E.L., Daniels, S.R. and Hall, A.V. (2017), "Social exchange theory: a critical review with theoretical remedies", The Academy of Management Annals, Vol. 11 No. 1, pp. 1-38.

Czypionka, T., Kocher, M.G. and Schnabl, A. (2020), "Österreichs wirtschaft in der Corona-pandemie", Perspektiven der Wirtschaftspolitik, Vol. 21 No. 3, pp. 280-289.

Daly, J.P. and Geyer, P.D. (1994), "The role of fairness in implementing large-scale change: employee evaluations of process and outcome in seven facility relocations", Journal of Organizational Behavior, Vol. 15 No. 7, pp. 623-638.

Danish, R.Q. and Usman, A. (2010), "Impact of reward and recognition on job satisfaction and motivation: an empirical study from Pakistan”, International Journal of Business and Management, Vol. 5 No. 2, pp. 159-167.

Dirani, K.M., Abadi, M., Alizadeh, A., Barhate, B., Garza, R.C., Gunasekara, N., Ibrahim, G. and Majzun, Z. (2020), "Leadership competencies and the essential role of human resource development in times of crisis: a response to Covid-19 pandemic", Human Resource Development International, Vol. 23 No. 4, pp. 380-394.

Dolnicar, S. and Hurlimann, A. (2011), "Water alternatives - who and what influences public acceptance?", Journal of Public Affairs, Vol. 11 No. 1, pp. 49-59.

Downs, C.W. and Hazen, M.D. (1977), “A factor analytic study of communication satisfaction”, Journal of Business Communication, Vol. 14 No. 3, pp. 63-73.
Employee support during the COVID-19 pandemic 
$\mathrm{JCOM}$ 25,3

Foa, E.B. and Foa, U.G. (1980), "Resource theory interpersonal behavior as exchange", in Gergen, K.J., Greenberg, M.S. and Willis, R.H. (Eds), Social Exchange, Advances and Theory and Research, Springer, Boston, MA, pp. 77-94.

Fornell, C.G. and Larcker, D.F. (1981), "Evaluating structural equation models with unobservable variables and measurement error", Journal of Marketing Research, Vol. 18 No. 1, pp. 39-50.

Frandsen, F. and Johansen, W. (2011), "The study of internal crisis communication: towards an integrative framework", Corporate Communications: An International Journal, Vol. 16 No. 4, pp. 347-361.

Fuller, C.M., Simmering, M.J., Atinc, G., Atinc, Y. and Babin, B.J. (2016), "Common methods variance detection in business research", Journal of Business Research, Vol. 69 No. 8, pp. 3192-3198.

Grunig, J.E. (1992), "What is excellence in management", in Grunig, J.E. (Ed.), Excellence in Public Relations and Communication Management, Routledge, New York, NY, pp. 219-250.

Hager, J. (2020), “Arbeitsmarkt: 1,3 Millionen in Österreich in Kurzarbeit, 517.221 ohne job”, Kurier, June 2 2020, available at: https://kurier.at/politik/inland/live-die-aktuellen-zahlen-zuarbeitslosigkeit-und-kurzarbeit/400928603 (accessed 10 January 2021).

Hair, J.F., Black, W.C., Babin, B.J. and Anderson, R.E. (2009), Multivariate Data Analysis, 7th ed., Pearson Education, Upper Saddle River, NJ.

Heide, M. and Simonsson, C. (2019), Internal Crisis Communication: Crisis Awareness, Leadership and Coworkership, Routledge, New York, NY.

Heide, M. and Simonsson, C. (2020), "Internal crisis communication: on current and future research", in Frandsen, F. and Johansen, W. (Eds), Crisis Communication, De Gruyter Mouton, Boston, Berlin, pp. 259-278.

Henseler, J., Ringle, C.M. and Sarstedt, M. (2015), "A new criterion for assessing discriminant validity in variance-based structural equation modeling”, Journal of the Academy of Marketing Science, Vol. 43 No. 1, pp. 115-135.

Hogg, M.A. and Belavadi, S. (2017), "Uncertainty management theories", in Hogg, M.A. and Belavadi, S. (Eds), Oxford Research Encyclopedia of Communication, Oxford University Press, Oxford, pp. 447-461.

Hu, L.T. and Bentler, P.M. (1999), "Cutoff criteria for fit indexes in covariance structure analysis: conventional criteria versus new alternatives", Structural Equation Modeling: A Multidisciplinary Journal, Vol. 6 No. 1, pp. 1-55.

Huang, Y. (2001), "OPRA: a cross-cultural, multiple-item scale for measuring organization-public relationships", Journal of Public Relations Research, Vol. 13 No. 1, pp. 61-90.

Jahansoozi, J. (2006), "Organization-stakeholder relationships: exploring trust and transparency”, The Journal of Management Development, Vol. 25 No. 10, pp. 942-955.

Jiang, H. and Men, R.L. (2017), "Creating an engaged workforce: the impact of authentic leadership, transparent organizational communication, and work-life enrichment", Communication Research, Vol. 44 No. 2, pp. 225-243.

Jiang, H. and Shen, H. (2020), "Toward a relational theory of employee engagement: understanding authenticity, transparency, and employee behaviors", International Journal of Business Communication. doi: 10.1177/2329488420954236.

Johansen, W., Aggerholm, H.K. and Frandsen, F. (2012), "Entering new territory: a study of internal crisis management and crisis communication in organizations", Public Relations Review, Vol. 38 No. 2, pp. 270-279.

Kahn, W.A. (1990), "Psychological conditions of personal engagement and disengagement at work", Academy of Management Journal, Vol. 33 No. 4, pp. 692-724.

Kang, M. and Sung, M. (2017), "How symmetrical employee communication leads to employee engagement and positive employee communication behaviors: the mediation of employeeorganization relationships", Journal of Communication Management, Vol. 21 No. 1, pp. 82-102. 
Kaur, P. and Mittal, A. (2020), "Meaningfulness of work and employee engagement: the role of affective commitment", The Open Psychology Journal, Vol. 13, pp. 115-122.

Kim, Y. (2018), "Enhancing employee communication behaviors for sensemaking and sensegiving in crisis situations. Strategic management approach for effective internal crisis communication", Journal of Communication Management, Vol. 22 No. 4, pp. 451-475.

Employee support during the COVID-19 pandemic

Kline, R.B. (1998), Principles and Practice of Structural Equation Modeling, The Guilford Press, New York, NY.

Lee, Y. and Li, Q.J.-Y. (2020), “The value of internal communication in enhancing employees' health information disclosure intentions in the workplace”, Public Relations Review, Vol. 46 No. 1, pp. 1-9.

Lemon, L. (2019), "The employee experience: how employees make meaning of employee engagement”, Journal of Public Relations Research, Vol. 31 Nos 5-6, pp. 176-199.

Mani, S. and Mishra, M. (2020), "Non-monetary levers to enhance employee engagement in organizations-'GREAT' model of motivation during the Covid-19 Crisis", Strategic HR Review, Vol. 19 No. 4, pp. 171-175.

Mann, A. and Dvorak, N. (2016), Employee Recognition: Low Cost, High Impact, Gallup, available at: www.gallup.com/businessjournal/193238/employeerecognition-low-cost-highimpact.aspx (accessed 13 August 2020).

Markos, S. and Sridevi, M.S. (2010), "Employee engagement: the key to improving performance", International Journal of Business and Management, Vol. 5 No. 12, pp. 89-96.

May, D.R., Gilson, R.L. and Harter, L.M. (2004), "The psychological conditions of meaningfulness, safety and availability and the engagement of the human spirit at work", Journal of Occupational and Organizational Psychology, Vol. 77 No. 1, pp. 11-37.

Mazzei, A. and Ravazzani, S. (2015), "Internal crisis communication strategies to protect trust relationships: a study of Italian companies", International Journal of Business Communication, Vol. 52 No. 3, pp. 319-337.

McGuinness, J. (2020), “4 COVID-19 leadership lessons”, Chief Executive, available at: https:// chiefexecutive.net/4-covid-19-leadership-lessons/ (accessed 10 January 2021).

Men, L.R. (2014), "Internal reputation management: the impact of authentic leadership and transparent communication", Corporate Reputation Review, Vol. 17 No. 4, pp. 254-272.

Men, L.R. and Bowen, S.A. (2017), Excellence in Internal Communication Management, Business Expert Press, New York.

Men, L.R. and Stacks, D.W. (2014), "The impact of leadership style and employee empowerment on perceived organizational reputation", Journal of Communication Management, Vol. 17 No. 2, pp. 171-192.

Men, L.R., O’Neil, J. and Ewing, M. (2020), “Examining the effects of internal social media usage on employee engagement", Public Relations Review, Vol. 46 No. 2, pp. 1-9.

Merritt, S.M. (2012), "The two-factor solution to Allen and Meyer's (1990) affective commitment scale: effects of negatively worded items", Journal of Business and Psychology, Vol. 27 No. 4, pp. 421-436.

Metselaar, E.E. (1997), "Assessing the willingness to change: construction and validation of the DINAMO”, Dissertation, VU, Amsterdam.

Meyer, J.P. and Allen, N.J. (1991), "A three-component conceptualization of organizational commitment", Human Resource Management Review, Vol. 1 No. 1, pp. 61-89.

Meyer, J.P. and Maltin, E.R. (2010), "Employee commitment and well-being: a critical review, theoretical framework and research agenda", Journal of Vocational Behavior, Vol. 77 No. 2, pp. 323-337.

Meyer, P., Stanley, J., Herscovitch, L. and Topolnytsky, L. (2002), "Affective, continuance, and normative commitment to the organization: a metaanalysis of antecedents, correlates, and consequences", Journal of Vocational Behavior, Vol. 61 No. 1, pp. 20-52. 
$\mathrm{JCOM}$ 25,3

Miller, V.D., Johnson, J.R. and Grau, J. (1994), "Antecedents to willingness to participate in a planned organizational change", Journal of Applied Communication Research, Vol. 22, pp. 59-80.

Mowday, R.T., Porter, L.W. and Steers, R.M. (1982), Employee-organization Linkages: The Psychology of Commitment, Absenteeism, and Turnover, Academic Press, New York, NY.

Orangefiery (2020), "Leadership communications during COVID-19: a survey of US organizations", available at: https://orangefiery.com/uploads/Orangefiery_COVID19_Leadership_ Communications_Research_040320.pdf (accessed 2 January 2021).

Peng, X. and Lee, S. (2019), "Self-discipline or self-interest? The antecedents of hotel employees' proenvironmental behaviours", Journal of Sustainable Tourism, Vol. 27 No. 9, pp. 1457-1476.

Peters, T. (1988), Thriving on Chaos: Handbook for a Management Revolution, Alfred A. Knopf, New York, NY.

Pollak, M., Kowarz, N. and Partheymüller, J. (2020), Chronologie zur Corona-Krise in Österreich - Teil 1: Vorgeschichte, der Weg in den Lockdown, die akute Phase und wirtschaftliche Folgen, Vienna Center for Electoral Research, Corona Blog, Vienna, available at: https://viecer.univie.ac.at/ corona-blog/corona-blog-beitraege/blog51/ (accessed 8 January 2021).

Poon, J.M.L. (2013), "Relationships among perceived career support, affective commitment, and work engagement", International Journal of Psychology, Vol. 48 No. 6, pp. 1148-1155.

Pugh, S.D. and Dietz, J. (2008), "Employee engagement at the organizational level of analysis", Industrial and Organizational Psychology, Vol. 1, pp. 44-447.

Rastogi, A., Prakash Pati, S., Krishnan, T.N. and Krishnan, S. (2018), "Causes, contingencies, and consequences of disengagement at work: an integrative literature review", Human Resource Development, Vol. 17 No. 1, pp. 62-94.

Rawlins, B.L. (2009), "Give the emperor a mirror: toward developing a stakeholder measurement of organizational transparency", Journal of Public Relations Research, Vol. 21 No. 1, pp. 71-99.

Rhoades, L., Eisenberger, R. and Armeli, S. (2001), "Affective commitment to the organization: the contribution of perceived organizational support”, Journal of Applied Psychology, Vol. 86, pp. 825-836.

Rich, B.L., Lepine, J.A. and Crawford, E.R. (2010), "Job engagement: antecedents and effects on job performance", Academy of Management Journal, Vol. 53 No. 3, pp. 617-635.

Roseman, I.J., Spindle, M.S. and Jose, P.E. (1990), "Appraisals of emotion-eliciting events. Testing a theory of discrete emotions", Journal of Personality and Social Psychology, Vol. 59 No. 5, pp. 899-915.

Rothbard, N.P. (2001), "Enriching or depleting? The dynamics of engagement in work and family roles", Administrative Science Quarterly, Vol. 46 No. 4, pp. 655-684.

Sagie, A. and Koslowsky, M. (1996), "International replication note. Decision type, organizational control, and acceptance of change: an integrative approach to participative decision making", Applied Psychology: International Review, Vol. 45 No. 1, pp. 85-92.

Saks, A.M. (2006), "Antecedents and consequences of employee engagement”, Journal of Managerial Psychology, Vol. 21 No. 7, pp. 600-619.

Saks, A.M. and Gruman, J.A. (2014), "What do we really know about employee engagement?", Human Resource Development Quarterly, Vol. 25 No. 2, pp. 155-182.

Schaufeli, W.B., Salanova, M., Gonzalez-Roma, V. and Bakker, A.B. (2002), "The measurement of engagement and burnout: a two sample confirmatory factor analytic approach", Journal of Happiness Studies, Vol. 3, pp. 71-92.

Seeger, M.W., Sellnow, T.L. and Ulmer, R.R. (2003), Communication and Organizational Crisis, Praeger, Westport, CT.

Shen, H. and Jiang, H. (2019), "Engaged at work? An employee engagement model in public relations", Journal of Public Relations Research, Vol. 31 Nos 1-2, pp. 32-49. 
Shuck, B., Reio, T.G. Jr and Rocco, T.S. (2011), "Employee engagement: an examination of antecedent and outcome variables", Human Resource Development International, Vol. 14 No. 4, pp. 427-445.

Smidts, A., Pruyn, T.H. and Riel, B.M. (2001), "The impact of employee communication and perceived external prestige on organizational identification", Academy of Management Journal, Vol. 44 No. 5, pp. 1051-1062.

Sonenshein, S. and Dholakia, U. (2012), "Explaining employee engagement with strategic change implementation: a meaning-making approach”, Organization Science, Vol. 23 No. 1, pp. 1-23.

Strack, R., von der Linden, C., Booker, M. and Strohmayr, A. (2014), Decoding Global Talent: 200,000 Survey Responses on Global Mobility and Employment Preferences, Boston Consulting Group, available at: www.handelsblatt.com/downloads/13816620/2/global_talent.pdf (accessed 13 August 2020).

Toscano, F. and Zappalà, S. (2020), "Social isolation and stress as predictors of productivity perception and remote work satisfaction during the COVID-19 pandemic: the role of concern about the virus in a moderated double mediation", Sustainability, Vol. 12 No. 23, pp. 1-14.

Van den Heuvel, M., Demerouti, E., Schreurs, B.H.J., Bakker, A.B. and Schaufeli, W.B. (2009), "Does meaning-making help during organizational change? Development and validation of a new scale", Career Development International, Vol. 14 No. 6, pp. 508-533.

Voorhees, C.M., Brady, M.K., Calantone, R. and Ramirez, E. (2016), "Discriminant validity testing in marketing: an analysis, causes for concern, and proposed remedies", Journal of the Academy of Marketing Science, Vol. 44 No. 1, pp. 119-134.

Wanberg, C.R. and Banas, J.T. (2000), "Predictors and outcomes of openness to change in a reorganizing workplace", Journal of Applied Psychology, Vol. 85 No. 1, pp. 132-142.

Weber, P.S. and Manning, M.R. (2001), "Cause maps, sensemaking, and planned organizational change", The Journal of Applied Behavioral Science, Vol. 37 No. 2, pp. 227-251.

Welch, M. (2011), "The evolution of the employee engagement concept: communication implications", Corporate Communications: An International Journal, Vol. 16 No. 4, pp. 328-346.

White, P. (2017), "How do employees want to be shown appreciation? Results from 100,000 employees", Strategic HR Review, Vol. 16 No. 4, pp. 197-199.

Wollard, K. (2011), "Quiet desperation: another perspective on employee engagement", Advances in Developing Human Resources, Vol. 13 No. 4, pp. 526-537.

Yin, N. (2018), "The influencing outcomes of job engagement: an interpretation from the social exchange theory", International Journal of Productivity and Performance Management, Vol. 67 No. 5, pp. 873-889.

Yue, C.A., Men, L.R. and Ferguson, M. (2019), "Bridging transformational leadership, transparent communication, and employee openness to change: the mediating role of trust", Public Relations Review, Vol. 45 No. 3, pp. 1-13.

\section{Corresponding author}

Sabine Einwiller can be contacted at: sabine.einwiller@univie.ac.at

For instructions on how to order reprints of this article, please visit our website:

www.emeraldgrouppublishing.com/licensing/reprints.htm

Or contact us for further details: permissions@emeraldinsight.com 